\title{
Does Investment in Fixed Assets Determine the Increase in Company Value?
}

\author{
Joanna Górna, Karolina Górna, Jakub Koziński*
}

\begin{abstract}
This article aims to identify the lack of connections between the occurrence of the investment and the change in the market price of a company as reflected in the price of its shares. The hypothesis is verified by the following: 1) volatility of a company's shares on the public market is dependent on the rate of investment; 2) sales value increase is dependent on the rate of investment. The hypothesis is verified using the econometrical Granger casualty test for dynamic panel data. The results of the study shows that there is no significant one-directional causality relation between the rate of investment and volatility of a company's shares on the public market and also sales value increase is not dependent on the rate of investment.
\end{abstract}

Keywords: fixed assets investments, stocks evaluation, company valuation

\section{Introduction}

Investment is the basis for the development of any company. That alone its origins can be understood as investment because there is a certain commitment to equity in order to achieve the objective. The most common goal of a company is to increase revenues, profits, efficiency and value.

Before making any investment decisions, each investment should be valued by professionals for profitability. Among the methods of investment one can point out those that are based on dynamic assessment, usually based on potential future cash flows and static ones which are based on book values. In theory, a well-executed investment should bring about undertaking the relevant benefits in the form of profits or increase the value of a company. Nevertheless, capital market experienced participants can note that this is not always reflected in the assessment investor as the price of a company's shares on the stock exchange. On the other hand, it may lead to a situation in which a wrong realized investment does not affect the decrease in the market value of a company.

The above-mentioned "anomalies" arise from the causes of the unusual activity of investors. These in turn, are not always efficient and not without reason in the science of finance as a rapidly growing part of behaviour. Technical analysts would note that regardless of

\footnotetext{
* Joanna Górna, MA; Nicolaus Copernicus University; e-mail: gorna.joanna@gmail.com; Karolina Górna, MA; Nicolaus Copernicus University; e-mail: gorna.karolina@gmail.com; Jakub Koziński, MA; University of Lodz; e-mail: jakub.kozinski@uni.lodz.pl.
} 
the basis of accounting (fundamental) price on the market can be guided by its own rules, depending on the forming of price formation and trends. Nevertheless, one has to note that technical analysis containing, according to the author, in their bases aspect of behavioural acts should be used only in the short term. Also target price or forecast value can be indicated. The solution may be a fundamental analysis, which did not take into account the behaviour of the market.

According to the author the very fact of investment in physical assets a company (irrespective of the date of its implementation) is assimilated in the price of the company on the market or in the increase of sales. Therefore, there is, according to the author, the link between the rate of investment in fixed assets on the market price of a company, although as indicated by Jabłoński and Jabłoński (2007) the investment in fixed assets should be one of the key measures of assessing a company's business. This work aims to identify connections between the occurrence of investment and change in the market price of the researched company as reflected in the price of its shares or sale value increase. Hypothesis verification is subject to the following: 1) volatility of the company's shares on the public market is dependent on the rate of investment; 2) sales value increase is dependent on the rate of investment.

\section{Investments}

Accounting Law indicates the investments as "assets held by the entity in or-der to achieve the economic benefits resulting from the increase in value of these assets are deductible in the form of interest, dividends (share of profits) or other benefits, including commercial transactions, in particular, these financial assets and real estate and intangible assets that are not used by the entity, but are held by it in order to achieve these benefits. In the case of insurance and reinsurance undertakings through investments meant deposits" (The Act of 29 September 1994) Therefore, it indicates only some of the assets.

Business practice is considered as an investment, however, action or effort to achieve a better future and benefits. The author intentionally shows here and distinguishes between action and effort. Not every fact must generate investment outlay, and can only rely on the action of abstention, for example, spending in order to achieve the advantage of increasing efficiency. An example of such an investment may be running modern methods of management in the company. Such investment does not generate financial investment (probably generates workload) but brings benefits, and its valuation is possible from the point of view of organizational benefits.

In this paper, due to the form of research, the investment should be under-stood as an increase in the value of assets year on year. It is known that the assets at the time of changing its value even through depreciation. It was assumed that the company has undertaken investments in fixed assets, if the value of fixed assets for the year increased or decreased by less than the value of the previous year minus depreciation. For the rate of investment is 
there-fore assumed to be the difference between the next and previous adjusted for depreciation. This gave the value of the real increase in (create new) assets in the company year on year.

\section{Fixed assets}

Fixed assets include:

- intangible assets,

- intangible fixed assets,

- long-term receivables,

- long-term investment,

- long-term prepayments.

Intangible assets are acquired property rights for economic use, with the expected economic cent-ness longer than 1 year, intended for their own entity, in particular copyrights, related rights, licenses, concessions, rights to inventions, patents, trademarks, designs and decorative and scientific (The Act of 29 September 1994).

Tangible fixed assets are the sum of fixed assets, fixed assets under construction and advances for fixed assets under construction. They are complete and fit for use, under construction, and the sum paid advances for not assets of the expected economic life of longer than one year. They must be designed for the needs of their own units, and also assets that belong to other individuals, but used and con-trolled by the company (The Act of 29 September 1994).

Long-term receivables are all due, or the power to demand payment on the maturity of more than twelve months. This period should be counted from the date of the report. In other words, these are all the debts that the company will receive for a period longer than twelve months from the date on which the accounts were closed, and no moment in which they were created.

Long-term investments are assets which in the long run have the wear-entity financial income resulting from an increase in their value, interest, dividends, etc. It is important that the assets were not actually used by the entity, and were acquired only in order to bring profit resulting from the above-mentioned reasons. For these investments, also known as permanent can be classified as real estate investments, intangible assets and financial assets fit for sale at more than twelve months from the time of their acquisition.

For long-term accruals do not include typical property values. This item attaches certain expenditure incurred by the operator for the accounting period in which the associated cost arose. 


\section{Enterprise value}

In the literature, the most commonly recognized goodwill is a twofold point of view: the methods of non-market and market (Dunal 2014). Among the first on the one hand is the book value, which is based on the value of its assets, and therefore can be seen in the balance sheets and reports. Damodaran (2007) indicates, however, that this value is deficient because it does not take into account the potential future benefits it can bring to the company. As a complementary non-market method this problem can be a profitable method. Damodaran (2007) indicates, however, that it is the concept of a capacity-market value of companies and thus one that takes into account the potential future cash flow generation, the risk of generating, as well as dynamic (if new information becomes available). Moreover, in the first group a mixed approach of assets and income can happen (Damodaran 2007).

According to the author what best reflects the value of the company is market valuation reflected in the valuation of its shares (shares). Market methods pre-suppose that the best information is provided by the market (Dunal 2014). Having the assumption native of a technical analysis, the market discounts everything; it is the stock price that takes into account both the book values (static) as well as the potential and risks of the company. In the study, the enterprise value is understood, therefore, just as the sum of shares (shares).

\section{Theoretical basis}

While verifying the undertaken hypothesis several econometrical methods and tools are used. A causality analysis and its implication into the econometrical modelling process is a subject of interest, due to the fact that it offers a wide range of instruments, which can be implemented during an investigation.

The way of understanding the causality itself may be a problematic issue. Since ancient times a lot of diverse concepts of causality have been invented and expanded. The most popular ones were created by famous philosophers, among whom the following should be introduced: Aristotle, Rene Descartes, Bayes, Hume, and Suppes.

The principal foundation of causation dependence is the causal determinism rule, which claims that every phenomenon has its own reason. According to the causal determinism rule the causal relation between two phenomenon's occurs if and only if one of the phenomenon, named cause, has an ability and power to generate a second phenomenon, named the result. The central idea of causality may be defined as follows:

'Phenomenon $\mathrm{C}$ is the cause for phenomenon $\mathrm{R}$, if in case $\mathrm{C}$ would not occur then $\mathrm{R}$ would not occur either.'

When expanding the analysis of causality with the problem of uncertainty (which is inseparable during any economical investigation), one can obtain successive types of determinations: random (weak), stochastic and functional (strong). 
A causation relationship is characterized by four inherent features: objectivity (causation relationship is independent of the observer or measuring equipment), recurrence, succession and generating power (which means that the cause has to be able to induce the result).

Different methods of introducing a causality analysis into econometrics were developed. Most popular are the works of:

1. H. Simon - he understands causality as a logical property of a deterministic model, which is describing a selected excerpt of reality.

2. H. Wold - he defines causality in a general sense: $\mathrm{X}$ is the cause for $\mathrm{Y}$, if one is able to control Y directly by controlling X. Inverse conduct - controlling X by controlling $\mathrm{Y}-$ is admissible in different time, which leads to the conclusion that $\mathrm{X}$ and $\mathrm{Y}$ both cannot be changed and controlled at the same time.

3. R.L. Basmann - a mechanism can be entitled as a causative if and only if every time it starts from an identical point, it has the tendency to run through the same sequence of cases. This definition focuses on the possibility of conducting a repetitive experiment, which occurs to be remarkably problematic in economics.

4. C. Granger - his concept of causality gained the largest popularity in econometrics. The central assumption of this concept is the fact that the result is the consequence of the cause, which means that the cause is previous to the result. Also, the cause is a carrier of the unique information of the result, which is inaccessible in any other way. As potential causes all information related with the result should be chosen.

The Granger causality is defined as follows (Osińska 2008):

- F $(\mathrm{Y} \mid \mathrm{X})$ - conditional distribution of $\mathrm{Y}$ given $\mathrm{X}$,

- $\Omega_{\mathrm{t}}-$ all information about the universe in moment $\mathrm{t}$,

$-\Omega_{t} \backslash X_{t}-$ all information about the universe in moment $t$, except that, which is enclosed in $X_{t}$,

and if a relation occurs:

$$
\Lambda_{\mathrm{k}>0} \mathrm{~F}\left(\mathrm{Y}_{\mathrm{t}+\mathrm{k}} \mid \Omega_{\mathrm{t}}\right)=\mathrm{F}\left(\mathrm{Y}_{\mathrm{t}+\mathrm{k}} \mid \Omega_{\mathrm{t}} \backslash \mathrm{X}_{\mathrm{t}}\right)
$$

then $\mathrm{X}_{\mathrm{t}}$ is not a cause for $\mathrm{Y}_{\mathrm{t}}$ in the Granger understanding of causality. It can be understood that if phenomenon $\mathrm{Y}$ occurs independently on phenomenon $\mathrm{X}$, then $\mathrm{X}$ is not the Granger cause of Y. In a diverse instance the Granger causality assumption is confirmed.

Because of the character of utilized data, to this investigation a dynamic panel model can be used, given as follow:

$$
\mathrm{y}_{\mathrm{i}, \mathrm{t}}=\sum_{\mathrm{k}=1}^{\mathrm{p}} \beta_{\mathrm{k}} \mathrm{y}_{\mathrm{i}, \mathrm{t}-\mathrm{k}}+\sum_{\mathrm{k}=0}^{\mathrm{p}} \theta_{\mathrm{k}} \mathrm{x}_{\mathrm{i}, \mathrm{t}-\mathrm{k}}+\mathrm{u}_{\mathrm{i}, \mathrm{t}}
$$

where:

$$
u_{i, t}=\alpha_{i}+v_{i, t} .
$$


In the case of not fulfilling the assumptions of the properties of estimators (i.e. consistence), appropriate methods should be used when dynamic panels are considered (DańskaBorsiak 2011). Those methods give the possibility to avoid problems such as: an unrealistic premise that affects one object or one period is not correlated to explanatory variables in the considered model, an assumption that at least part of the independent variables are endogenous.

One of the proper methods is the GMM (the General Moments Method). Using the GMM requires taking the following steps (the Arellano \& Bond method 1991):

1) regression should be written in dynamic form (including variable lag);

2) differences $\Delta$ must be calculated in the case of eliminating individual effects for every object. Under the assumption that the initial model for period thas the following form:

$$
\mathrm{y}_{\mathrm{i}, \mathrm{t}}=\alpha+(1-\beta) \mathrm{y}_{\mathrm{i}, \mathrm{t}-1}+\mu_{\mathrm{i}}+\mathrm{v}_{\mathrm{i}, \mathrm{t}},
$$

and for the period $\mathrm{t}-1$ :

$$
y_{i, t-1}=\alpha+(1-\beta) y_{i, t-2}+\mu_{i}+v_{i, t-1},
$$

The model can be presented first as the differences of a dependent variable:

$$
\Delta y_{i, t}=(1-\beta) \Delta y_{i, t-1}+\Delta v_{i, t} .
$$

When that model hypothesis is used, individual effects are removed. So the assumption that those effects and dependent variables are not correlated is not required, as that problem then does not occur;

3) to the model must be implemented instruments. The aim of this is to eliminate the endogenous character of variables. Due to that the problem of inconsistency of the estimator is solved. The proper instrument is a variable which is correlated to a variable for which the instrument is proposed but is not correlated to the residuals of the estimated model. Usually good instruments are lagged variables.

In some cases the GMM estimator can appear biased. This situation takes place, when instruments are not properly chosen and are weakly correlated to explanatory variables (Bond, Hoeffler, Temple 2001).

\section{The Granger causality test for dynamic panel data}

One of the approaches applied in testing causality in dynamic panel data is the one proposed by Hurlin and Venet or Hurlin (Hurlin 2004). It is adequate for short panels (in this investigation $T=5)$. It is verified if $x_{i, t}(i \in[1, N])$ is the cause of $y_{i, t}$, which means that knowing the value of $x_{i, t}$ simplifies evaluation the value of $y_{i, t}$. 
Testing consists in estimating two models - first, in which values of the dependent variable are explained only by its lags and second, which additionally consist of explanatory variable (model (1)):

1) model $\mathrm{I}-\mathrm{y}_{\mathrm{i}, \mathrm{t}}=\sum_{\mathrm{k}=1}^{\mathrm{p}} \gamma_{\mathrm{k}} \mathrm{y}_{\mathrm{i}, \mathrm{t}-\mathrm{k}}+\mathrm{u}_{\mathrm{i}, \mathrm{t}}$ ),

2) model II $-\mathrm{y}_{\mathrm{i}, \mathrm{t}}=\sum_{\mathrm{k}=1}^{\mathrm{p}} \gamma_{\mathrm{k}} \mathrm{y}_{\mathrm{i}, \mathrm{t}-\mathrm{k}}+\sum_{\mathrm{k}=0}^{\mathrm{p}} \beta_{\mathrm{k}} \mathrm{x}_{\mathrm{i}, \mathrm{t}-\mathrm{k}}+\mathrm{u}_{\mathrm{i}, \mathrm{t}}$.

Having those models estimated leads to three consecutive tests:

1) HINC - homogenous and instantaneous non-causality hypothesis - the test procedure is directed towards testing whether or not the $\beta_{\mathrm{k}}$ 's of $\mathrm{x}_{\mathrm{i}, \mathrm{t}-\mathrm{k}}$ are simultaneously null for all individual $\mathrm{i}$ and all lag $\mathrm{k}$ :

$$
\begin{aligned}
& \mathrm{H}_{0}: \beta_{\mathrm{k}}=0 \forall \mathrm{i} \in[1, \mathrm{~N}], \forall \mathrm{k} \in[0, \mathrm{p}] \\
& \mathrm{H}_{1}: \beta_{\mathrm{k}} \neq 0 \exists(\mathrm{i}, \mathrm{k}) .
\end{aligned}
$$

The following Wald statistics are used:

$$
\mathrm{F}_{\mathrm{HINC}}=\frac{\left(\mathrm{SSR}_{\mathrm{I}}-\mathrm{SSR}_{\mathrm{II}}\right) /(\mathrm{Np})}{\mathrm{SSR}_{\mathrm{II}} /[\mathrm{NT}-\mathrm{N}(1+\mathrm{p})-\mathrm{p}]}
$$

where:

$\mathrm{SSR}_{\mathrm{I}}$ - the sum of the squares of the residuals from model I,

$\mathrm{SSR}_{\mathrm{II}}$ - the sum of the squares of the residuals from model II.

If the null hypothesis is rejected, then the occurrence of the Granger causality is confirmed. Following tests should be run. In other cases, between the analysed processes the causality relations do not exist.

2) $\mathrm{HC}$ - homogenous causality hypothesis - takes place if all the coefficients $\beta_{\mathrm{k}}$ are identical for all lag $\mathrm{k}$ and are statistically different from zero. They are tested whether or not $\beta_{\mathrm{k}}$ are equal to each other. The following hypotheses are tested:

$$
\begin{aligned}
& \mathrm{H}_{0}: \beta_{\mathrm{k}}^{\mathrm{i}}=\beta_{\mathrm{k}}^{\mathrm{j}} \forall \mathrm{i}, \mathrm{j} \in[1, \mathrm{~N}], \forall \mathrm{k} \in[0, \mathrm{p}] \\
& \mathrm{H}_{1}: \beta_{\mathrm{k}}^{\mathrm{i}} \neq \beta_{\mathrm{k}}^{\mathrm{j}} \exists(\mathrm{i}, \mathrm{k}) .
\end{aligned}
$$

The following statistics are calculated:

$$
\mathrm{F}_{\mathrm{HC}}=\frac{\left(\mathrm{SSR}_{\mathrm{I}}-\mathrm{SSR}_{\mathrm{II}}\right) /[\mathrm{p}(\mathrm{N}-1)]}{\mathrm{SSR}_{\mathrm{II}} /[\mathrm{NT}-\mathrm{N}(1+\mathrm{p})-\mathrm{p}]}
$$

If the homogenous causality hypothesis will be rejected it means that the values of the process for individual objects vary in explaining $\mathrm{Y}$ or that some objects have influence on $\mathrm{Y}$ and some do not. So when it is concluded that correct is $\mathrm{H}_{1}$ should be run as a heterogeneous non-causality test. 
3) HENC - heterogeneous non-causality hypothesis - for each cross-section unit, the nullity of all the coefficients of the lagged explanatory variable $\mathrm{x}_{\mathrm{i}, \mathrm{t}-\mathrm{k}}$ are tested. The hypotheses under this case are:

$$
\begin{aligned}
& \mathrm{H}_{0}: \theta_{\mathrm{k}}^{\mathrm{i}}=0 \forall \mathrm{i} \in[1, \mathrm{~N}], \forall \mathrm{k} \in[0, \mathrm{p}] \\
& \mathrm{H}_{1}: \theta_{\mathrm{k}}^{\mathrm{i}} \neq 0 \forall \mathrm{i} \in[1, \mathrm{~N}], \forall \mathrm{k} \in[0, \mathrm{p}] .
\end{aligned}
$$

The following Wald statistics are used:

$$
\mathrm{F}_{\mathrm{HENC}}=\frac{\left(\mathrm{SSR}_{\mathrm{I}}-\mathrm{SSR}_{\mathrm{II}}\right) / \mathrm{p}}{\mathrm{SSR}_{\mathrm{II}} /[\mathrm{NT}-\mathrm{N}(1+2 \mathrm{p})+\mathrm{p}]}
$$

If the null hypothesis is not rejected, it means that there is a subset of objects that are not the cause of the investigated process $\mathrm{Y}$. The alternative hypothesis informs that different objects vary in explaining $\mathrm{Y}$ but all of them have influence on the dependent variable.

\section{Study and the results}

The aim of the conducted investigation was to find the answer to the question of if there can be observed one-directional causality relations between the rate of investments and increase rate of revenues and between the rate of investments and increase rate of share prices? So the following models were estimated:

1) dynamic panel model for revenues:

where:

$$
\mathrm{P}_{\mathrm{i}, \mathrm{t}}=\alpha_{0}+\alpha_{1} \mathrm{P}_{\mathrm{i}, \mathrm{t}-1}+\mathrm{u}_{\mathrm{i}, \mathrm{t}}
$$

$\mathrm{P}_{\mathrm{i}, \mathrm{t}}$ - increase rate of revenues of company $\mathrm{i}$ in year $\mathrm{t}$,

$\mathrm{P}_{\mathrm{i}, \mathrm{t}-\mathrm{1}}$ - increase rate of revenues of company $\mathrm{i}$ in the previous year;

2) dynamic panel model for increase rate of revenues with independent variable investments:

$$
\mathrm{P}_{\mathrm{i}, \mathrm{t}}=\alpha_{0}+\alpha_{1} \mathrm{P}_{\mathrm{i}, \mathrm{t}-1}+\alpha_{2} \mathrm{I}_{\mathrm{i}, \mathrm{t}}+\mathrm{u}_{\mathrm{i}, \mathrm{t}}
$$

$I_{i, t}-$ rate of investments in company $i$ in year $t$;

3) dynamic panel model for increased rate of share prices:

$$
\mathrm{S}_{\mathrm{i}, \mathrm{t}}=\alpha_{0}+\alpha_{1} \mathrm{~S}_{\mathrm{i}, \mathrm{t}-1}+\alpha_{2} \mathrm{~S}_{\mathrm{i}, \mathrm{t}-2}+\mathrm{u}_{\mathrm{i}, \mathrm{t}}
$$

$S_{i, t}$ - increased rate of share prices of company $i$ in year $t$,

$\mathrm{S}_{\mathrm{i}, \mathrm{t}-\mathrm{1}}$ - increased rate of share prices of company $\mathrm{i}$ in the previous year; 
4) dynamic panel model for increased rate of share prices with independent variable investments:

$$
\mathrm{S}_{\mathrm{i}, \mathrm{t}}=\alpha_{0}+\alpha_{1} \mathrm{~S}_{\mathrm{i}, \mathrm{t}-1}+\alpha_{2} \mathrm{~S}_{\mathrm{i}, \mathrm{t}-2}+\alpha_{3} \mathrm{I}_{\mathrm{i}, \mathrm{t}}+\mathrm{u}_{\mathrm{i}, \mathrm{t}}
$$

The results of the estimation model for the increased rate of revenues are shown in Table 1. Value of estimated parameter for lag revenues shows that the companies' sale value growth rate is strictly connected with its increase rate of revenues gained in the previous year. The Sargan test informs that the instruments used in the estimation were correctly established.

\section{Table 1}

Estimation of the dynamic panel model for Revenues given by (5)

\begin{tabular}{lll}
\hline Parameter & Estimation & p-value \\
\hline$\alpha_{0}$ & -0.01996 & 0.8882 \\
$\alpha_{1}$ & 0.0000 \\
\hline SSR 17483.23 & \\
\hline Sargan $\chi^{2}=4,2738(\mathrm{p}$-value $=0.4248)$ & \\
\hline
\end{tabular}

Source: own calculations.

Introducing to model (5) the values of the investment rates provides a model given by (6). The results are shown in Table 2 . The extended revenue model unfortunately does not better explain the examined issue. P-value for parameter $\alpha_{2}$ shows that the rate of the investments are not statistically significant. Also, the higher value of the sum of squares of the residuals arrives at the conclusion that model (6) should not be considered.

\section{Table 2}

Estimation of the dynamic panel model for the Revenues given by (6)

\begin{tabular}{lll}
\hline Parameter & Estimation & p-value \\
\hline$\alpha_{0}$ & -0.02970 & 0.8480 \\
$\alpha_{1}$ & -0.22405 & 0.0000 \\
$\alpha_{2}$ & -0.26086 & 0.6595 \\
\hline SSR 17562.79 & \\
\hline Sargan $\chi^{2}=4.82995(\mathrm{p}$-value $=0.4370)$ & \\
\hline
\end{tabular}

Source: own calculations.

Prior calculations were used to verify the causality hypothesis. The first test procedure, named as the homogenous and instantaneous non-causality hypothesis, is provided by the HINC test. Then results are presented in Table 3. 
Table 3

The HINC test for process Revenues

\begin{tabular}{lr}
\hline HINC & \multicolumn{1}{l}{ Value } \\
\hline SSR: $P_{i, t}=\alpha_{0}+\alpha_{1} P_{i, t-1}+u_{i, t}$ & $17,483.23$ \\
SSR: $P_{i, t}=\alpha_{0}+\alpha_{1} P_{i, t-1}+\alpha_{2} I_{i, t}+u_{i, t}$ & $17,562.79$ \\
\hline $\mathrm{F}_{\text {HINC }}$ & -0.0135 \\
\hline $\mathrm{F}_{0,005 ; 100 ; 299}^{*}$ & 0.7556 \\
\hline Hypothesis & non-causality \\
\hline
\end{tabular}

Source: own calculations.

The test confirms that parameter $\alpha_{2}$ is null. This only proves the conclusion obtained from the models' estimation. Because the hypothesis about non-causality is not rejected, the next steps of verification will not be taken as unnecessary. Provided that the investigation can lead to the assumption, that the rate of investments does not imply changes in the revenues growth rate.

The analogous investigation was conducted to verify whether there is or not a causality relation between share price increase and investment rate. The results of the estimation of model (7) are presented in Table 4.

\section{Table 4}

Estimation of the dynamic panel model for the share prices given by (7)

\begin{tabular}{lll}
\hline Parameter & Estimation & p-value \\
\hline$\alpha_{0}$ & -0.07118 & 0.0601 \\
$\alpha_{1}$ & -0.37349 & 0.0000 \\
$\alpha_{2}$ & -0.36288 & 00000 \\
\hline SSR 44.95527 & \\
\hline Sargan $\chi^{2}=25.3594(\mathrm{p}$-value $=0.0000)$ & \\
\hline
\end{tabular}

Source: own calculations.

The model above shows that share price increase rates are strictly dependent on their values in the former periods. Although, the model is not satisfying, what are visible are the values of the Sargan test. Testing the causality relation model was modified by introducing another variable - rate of investments (Table 5). 


\section{Table 5}

Estimation of the dynamic panel model for share prices given by (8)

\begin{tabular}{lll}
\hline Parameter & Estimation & p-value \\
\hline$\alpha_{0}$ & -0.07110 & 0.0637 \\
$\alpha_{1}$ & -0.37341 & 0.0000 \\
$\alpha_{2}$ & -0.36277 & 0.0000 \\
$\alpha_{3}$ & 0.00182 & 0.9822 \\
\hline
\end{tabular}

SSR 44.96044

Sargan $\chi^{2}=25.2542(\mathrm{p}$-value $=0.0000)$

Source: own calculations.

The presented results are similar to those for the previous part of the investigation. In this case, the independent variable is not statistically significant. For further verification, the HINC test was provided.

\section{Table 6}

The HINC test for process share prices

\begin{tabular}{ll}
\hline HINC & Value \\
\hline SSR: $\mathrm{S}_{\mathrm{i}, \mathrm{t}}=\alpha_{0}+\alpha_{1} \mathrm{~S}_{\mathrm{i}, \mathrm{t}-1}+\alpha_{2} \mathrm{~S}_{\mathrm{i}, \mathrm{t}-2}+\mathrm{u}_{\mathrm{i}, \mathrm{t}}$ & 44.95527 \\
SSR: $\mathrm{S}_{\mathrm{i}, \mathrm{t}}=\alpha_{0}+\alpha_{1} \mathrm{~S}_{\mathrm{i}, \mathrm{t}-1}+\alpha_{2} \mathrm{~S}_{\mathrm{i}, \mathrm{t}-2}+\alpha_{3} \mathrm{I}_{\mathrm{i}, \mathrm{t}}+\mathrm{u}_{\mathrm{i}, \mathrm{t}}$ & 44.96044 \\
\hline $\mathrm{F}_{\mathrm{HINC}}$ & -0.0003 \\
\hline $\mathrm{F}_{0,005 ; 100 ; 299}^{*}$ & 0.7556 \\
\hline Hypothesis & non-causality \\
\hline
\end{tabular}

Source: own calculations.

Not surprisingly, the HINC test led to a similar conclusion as in the revenues. Between the rate of investments and share prices the increase rate one-directional causality relation is not present. This only confirms the motion obtained from the t-Student test.

\section{Conclusions}

Investment is the basis of the development of each company. That alone its origins can be understood as an investment because it is a certain commitment to equity in order to achieve the objective. In theory, a well-executed investment should bring undertaking the relevant benefits in the form of profits or increase the value of the company. Nevertheless, capital market experienced participants can note that this is not always reflected in the assessment investor as the price of the company's shares on the stock exchange or revenue increase. 
The results of the study show that there is no significant one-directional causality relation between the rate of investment and volatility of the company's shares on the public market and also sales value increase is not dependent on the rate of investment. Both hypothesis are verified negatively. This might indicate the fact that investment in fixed assets (increases a company's book value) is the reason why the companies value is higher, and not the result of these investments.

\section{References}

Bond S., Hoeffler A., Temple J. (2001), GMM Estimation of Empirical Growth Models.

Caputa W. (2011), Wycena i ewidencja inwestycji rzeczowych w systemie rachunkowości, Zeszyty Naukowe Politechniki Śląskiej "Organizacja i Zarządzanie".

Damodaran A. (2007), Finanse korporacyjne, Helion, Gliwice.

Dańska-Borsiak B. (2011), Dynamiczne Modele Panelowe w Badaniach Ekonomicznych, Wydawnictwo Uniwersytetu Łódzkiego, Łódź.

Dunal P. (2014), Rynkowe metody wyceny przedsiębiorstw, "Folia Oeconomica" vol. 2, no. 300, Łódź.

Erdil E., Yetkiner I.H. (2004), A Panel Data Approach for Income-Health Causality, FNU-47.

Gawrońska Z., Makarska A. (2012), Wpływ struktury kapitału na wartość przedsiębiorstwa, "Nierówności Społeczne a Wzrost Gospodarczy" nr 27, Uniwersytet Szczeciński.

Hurlin C. (2004), Testing Granger Causality in Heterogenous Panel Data Models with Fixed Coefficients, Mimeo, University Orleans.

Jabłoński M., Jabłoński A. (2007), Kluczowe miary biznesowe w budowie wartości firmy, Zeszyty Naukowe Wyższej Szkoły Humanitas, z. 2, Sosnowiec.

Jaworek M., Kuzel M. (2013), Aktywność inwestycyjna największych przedsiębiorstw w Polsce, in: Inwestowanie w Aktywa Rzeczowe i Finansowe, Zeszyty Naukowe Wy-działowe Uniwersytetu Ekonomicznego w Katowicach.

Osińska M. (2008), Ekonometryczna analiza zależności przyczynowych, Wydawnictwo Naukowe UMK, Toruń.

Tulasi Devi S.L., Investment Analysis in Fixed Assets, in: International Journal of Humanities and Applied Sciences, vol. 1 , no. 1 .

Ustawa o rachunkowości z dnia 29 września 1994 r. (Dz.U. 2013, poz. 330, 613, z 2014 r. poz. 768).

\section{CZY INWESTYCJE W ŚRODKI TRWALE USTALA SPÓŁKA O ZWIĘKSZONEJ WARTOŚĆ?}

Streszczenie: Niniejszy artykuł ma na celu ukazanie braków połączeń między wystąpieniem inwestycji, zmianie ceny rynkowej spółki w odzwierciedleniu do ceny akcji spółki. Hipoteza jest weryfikowana przez: 1) zmienność akcji spółki na rynku publicznym jest uzależniona od wysokości inwestycji; 2) wzrost wartości sprzedaży jest uzależniony od stopy inwestycji. Hipotezy są weryfikowane przy użyciu testu Grangera dla dynamicznych danych panelowych. Wyniki badania pokazują, że nie ma istotnego jednokierunkowego związku przyczynowego między stopą inwestycji a zmiennością akcji spółki na rynku publicznym, a także wzrost wartości sprzedaży nie jest uzależniony od wysokości inwestycji.

Słowa kluczowe: inwestycje, środki trwałe, ocena zasobów, wycena spółki

\section{Citation}

Górna J., Górna K., Koziński J. (2015), Does Investment in Fixed Assets Determine the Increase in Company Value?, Zeszyty Naukowe Uniwersytetu Szczecińskiego nr 855, „Finanse, Rynki Finansowe, Ubezpieczenia” nr 74, t. 1, Wydawnictwo Naukowe Uniwersytetu Szczecińskiego, Szczecin, s. 409-420; www.wneiz.pl/frfu. 